\title{
Neoliberalism, Voice and National Media Systems: An Interview with Terry Flew ${ }^{1}$
}

\author{
SIMON DAWES, Université Paul Valéry, Montpellier, France \\ TERRY FLEW, Queensland University of Technology, Brisbane, Australia
}

\begin{abstract}
In this interview, Terry Flew discusses the continued relevance of the nation-state and national media systems in an era of globalization, and the need for cross-national comparative research in media studies. He also discusses the benefits of the concepts of 'voice' and 'participation' over 'citizenship' for evaluating media systems, and criticises the overblown and dismissive use of 'neoliberalism' as a rhetorical flourish, in favour of developing it as an analytical concept grounded in empirical evidence. Drawing on Foucault's work on both Weber and neoliberalism, Flew argues, helps us recognise the need for comparative work on institutions and national systems of government.
\end{abstract}

\section{KEYWORDS}

Max Weber, Media Systems, Michel Foucault, Neoliberalism, Voice

SIMON DAWES: You've recently (Flew \& Waisbord 2015; Flew et. al., 2016) criticised claims that media globalization is weakening the relevance of nation-states, and argued for the continuing centrality of nation-states to media processes and the ongoing significance of national space, as well as the continued relevance of Hallin \& Mancini's model of media systems. To what extent can such a position be reconciled with an acknowledgment of the impact of transnational forces within national media institutions, policies and cultures?

TERRY FLEW: Media globalization is certainly one of a number of forces impacting upon $20^{\text {th }}$ century models of media policy. Platform convergence, the rise of digital platforms that are not themselves commissioners or creators of content, and user-created content are among others reshaping media policy worldwide. My point would be that the impact of media globalisation on nation-states depends to a degree upon what kinds of state we are talking about. Where states are strong, transnational forces are to a degree subordinate to national governments: China is the obvious case in point here. More generally, insofar as profitability in media industries hinges upon privileged forms of access to certain kinds of audiences, transnational media companies face the challenge of how to deal with national governments,

\footnotetext{
${ }^{1}$ This interview is part of a special section of interviews on 'Neoliberalism, Media and Power', edited by Simon Dawes and also featuring interviews with Des Freedman and Sean Phelan. Available at: http://ojs.meccsa.org.uk/index.php/netknow/issue/archive
} 
particularly where they are in competition with incumbents with a long history of engagement in these political cultures, and where politicians - particularly in Europe - are inclined to want to promote their 'national champions', to deal with 'the threat of Google' and other perceived threats from outside of their borders. So political, economic and cultural nationalisms remain relevant in the world that faces global media companies.

SIMON DAWES: You've argued for the need for more cross-national comparative research in media studies. You're critical, however, of comparative studies that remain largely descriptive, and which are primarily interested in understanding national differences, rather than developing alternative explanations and theories. How can the more reflexive comparative research that you encourage help us move beyond the replication of the scholarly priorities of UK and US researchers?

TERRY FLEW: Comparative research is necessary because we bring many unconscious biases to media research. For example, most Internet users in the world deal with an Internet that is considerably more governed than discourses that are informed by the First Amendment of the U.S. Constitution would have you believe. But what is needed is not a descriptive comparativism; how many smart phones are there in, say, India, as compared to Indonesia. The point is that there are a lot in both countries, and what we need to understand are the resulting socio-cultural shifts. Getting a greater global plurality of perspectives requires engaging with the global political-economy of scholarly publishing, which remains dominated by the U.S. and the English-speaking world. The global movement of graduate students is also a relevant factor here.

SIMON DAWES: Australia has had a dual broadcasting system since the inception of broadcasting, and currently has one of most concentrated newspaper systems in the democratic world (Flew 2013). How would you summarise the differences between Australian and UK media systems - in terms of market competition, concentration and plurality, the promotion of core social democratic values through regulation, and the influence of Rupert Murdoch?

TERRY FLEW: Rupert Murdoch's influence over Australian politics is MUCH greater than that of the UK. In the 2013 Federal election, Murdoch's newspapers universally ran an antiLabor line, and there was a very close relationship between former Prime Minister Tony Abbott and the Murdoch editors and columnists. My point would be that this generates far less influence over political debate than was the case 30 years ago. Newspaper circulations are a fraction of what they once were, and people access political information from a multiplicity of online and social media sources. Also, at least in Australia, the political leadership cycle is 
far more brutal than it once was. When the former Liberal leader, Tony Abbott, lost popular support, all the favourable columns in Murdoch newspapers could not put that back together.

Australian governments have long restricted competition in broadcasting, in part so that profitable commercial networks would reinvest these profits in local production. This has been done not only with the support of governments from both sides of politics, but with the tacit support of much of the local production industry. Policy measures that opened up the broadcasting market would threaten that particular quid pro quo between the commercial networks and the local production industry. When the Productivity Commission questioned both the desirability and sustainability of this back in 2000 (Productivity Commission 2000), their arguments were largely howled down by the sector itself, and the Howard government in spite of its alleged neoliberalism - quickly buried this outline of an agenda for more market-oriented reforms of Australian media policy. Now that OTT (over-the-top) services like Netflix are challenging the dominance of the networks anyway, the question of how best to support local production is likely to be revisited. My point would be that a more competitive market does not necessarily deliver to cultural progressives the things they also desire, such as continued investment in local content or children's programming.

SIMON DAWES: Like Nick Couldry (2010), you have also (2009) drawn on Albert Hirschmann to argue that a focus on "voice" and "participation" is a less problematic alternative to normative applications of "citizenship" as an evaluative framework, although you recognise that notions of citizenship have been implicit throughout the development of broadcasting policy since its inception. Could you say a little more about the problems you have with the tendency, particularly among British scholars, to present "citizen" and "consumer" as alternative discursive positions, to present citizenship in normative terms, and to retrofit a citizenship discourse onto earlier media institutions?

TERRY FLEW: Nick Couldry has done media studies a great service in drawing attention to Albert Hirschmann's concept of 'voice', in his 1970 book Exit, Voice and Loyalty. What Hirschmann does is bring out the extent to which a political and participatory logic towards social institutions, captured in the concept of 'voice', co-exists with the more strictly economic logic of 'exit'. Hirschmann also identified the extent to which systems based entirely upon 'exit', or upon consumer choice as the primary means of registering decisions, can generate their own contradictory consequences. This was 20 years before we started to be clear about the practical limits of privatising forms of public infrastructure such as rail networks and energy utilities, which was the risk of simply replacing imperfect public monopolies with private monopolies that had no public accountability.

In response to the question, the risk in using 'exit' and 'voice' is that you simply take them as being synonymous with 'private' and 'public'. There are very interesting forms of consumer activism that engage around markets and citizenship, that range from ethical investment to divestment campaigns, to some forms of food activism. At the same time, the line between 
commercial and state-run can be drawn too neatly with regards to media. There is certainly a history of commercial media engaging in programming that has citizenship dimensions. In Australia, for example, the mini-series functioned as a kind of historical story-telling medium for a mass audience. At the same time, our public service media are not averse to content decisions that seek to maximise audiences. Watching BBC1 on any given night of the week, I would suggest there are a whole range of programs whose claims to being concerned with citizenship are very thin. They are popular programs aimed at mass audiences.

So perhaps we need to accept that social institutions, both public and private, are complex assemblages that require detailed historical and institutional analysis. Simply saying that institutional form $\mathrm{X}$ only engages with people as consumers, whereas $\mathrm{Y}$ only engages with them as citizens, is a simplistic dualism that scholarly work in the field needs to get beyond.

SIMON DAWES: Pointing to a lack of convergence even within countries of the same media system, you dismiss the argument that there has been a global trend of policy convergence across national media systems. You also argue that "neoliberalism" (as a political ideology) does not sufficiently explain global policy trends, and that neoliberalism is no more a hegemonic influence on public policy than national or state capitalism. You accept that the term can, however, help explain certain trends in the US and the UK - but only 'debatably'. To what extent do you think that neoliberalism does not convincingly explain, for instance, trends in UK broadcasting policy over the past few decades?

TERRY FLEW: According to the BBC series Masters of Money, Prime Minister Margaret Thatcher used to keep quotes from Freidrich von Hayek on pieces of paper in her handbag, and would refer to them in Cabinet meetings when she felt that her Ministerial colleagues were deviating too much from the true path. That is what a dedication to implementing neoliberalism in public life looks like!

The use of the term in academic circles has now, however, become so sloppy that I think there is a danger in continuing to see it as a core analytical category. It is routinely invoked to explain everything from the rise of Bollywood themed weddings to competitive cooking shows to university departmental restructurings. In public discourse, it has become an illdefined abuse term. In the UK, for instance, there is a healthy coterie of commenters on The Guardian's online comments section for whom anyone who expresses a view that positions them at odds with Jeremy Corbyn is, by definition, a neoliberal. In debating the uses and abuses of this term with an academic colleague in the humanities recently, I found that his view - and he is an internationally well-known cultural studies theorist - was that anyone who did not believe that neoliberalism was the dominant ideology of our times was an agent of neoliberal ideology, since disavowal of neoliberalism was the surest sign of a neoliberal. The propensity of all of this to lapse into a kind of conspiracy theory is readily apparent. 
It is also not a particularly important animating principle for media policy. It could be: if, for instance, we completely removed broadcasting licencing systems and privatised the BBC, that would certainly be a neoliberal direction in media policy in the UK. But most policy makers around the world are approaching media policy reform far more cautiously than this. We also need to be cautious about framing policy discourses too readily within a neoliberal/antineoliberal frame. In the UK, the question of whether licence fees can continue to fund the $\mathrm{BBC}$ into the future is a real one, and it is not necessarily 'neoliberal' to question both the equity and the sustainability of the current arrangements.

The final point is that much of the world does not work along these lines. In its adoption of a market economy, China has not furthered political liberalisation at all: liberalism is a historically weak force in China, and the Communist Party of China repeatedly positions liberalism as a threat to the Chinese nation. Putin's Russia would appear to be increasingly a state capitalist system. The developmental state models of East Asia have always supported pragmatic state interventions in the underlying economic structure.

SIMON DAWES: In recent years (2012; 2014; 2015), you have been focusing on Foucault's lectures on neoliberalism, and engaging with the theoretical debates on how best to understand neoliberalism. You've criticised the tendency of many scholars to use the term as a conceptual trash-can, “...into which anything and everything can be dumped, as long as it is done so with suitable moral vehemence", and written about the need to "rescue' the concept from the most vocal moral critics of markets and economic discourse, whom you accuse of producing functionalist and instrumentalist accounts of the state. Is the way in which critical scholars use the term 'neoliberalism' beginning to change?

TERRY FLEW: Michel Foucault's lectures at the College de France in 1978-79, published in English in 2008 as The Birth of Biopolitics, were very important in giving the concept of neoliberalism some analytical rigour. Rather than just being an abuse term, that critical humanities scholars came to do to denounce anything to do with economics and markets, neoliberalism was now being seen as part of an important historical moment, where economists associated with the 'Austrian School' (led by Hayek, and inspired by von Mises and Schumpeter) and the 'Chicago School' (Milton Friedman, George Stigler etc.), as well as the 'Virginia School' of James Buchanan and the 'public choice' theorists, were turning their critique of Keynesian economics and government intervention into markets into a wider set of ideas about the relationship between political economy and social order. Rather ingeniously, Foucault proposes that post-WWII (West) Germany provided a policy test-bed for some of these ideas, such as 'positive' welfare (i.e. the purpose of welfare is not poverty alleviation, but getting people back into the workforce), prioritising monetary policy and low inflation over full employment, and the idea of an 'enterprise society'.

The late translation of Foucault's lectures into English has had some interesting consequences. Their publication in 2008 coincided with a global financial crisis that many 
blamed on the deregulation of financial markets since the 1980s, and an associated rise in both consumer debt and risky lending by financial institutions. It has been followed by important critiques of global capitalism coming from relatively mainstream economists, such as Thomas Piketty with his voluminous and very data-driven Capital in the Twenty-First Century (Piketty, 2014). So talk about neoliberalism has been moving beyond being essentially a rhetorical flourish - akin to calling something 'petty bourgeois' or calling someone a 'Red Tory' - to appearing as a sound analytical concept grounded in empirical evidence.

SIMON DAWES: You've also been critical of some accounts of neoliberalism that present a trouble-free amalgamation of Foucault's ideas into a generic, neo-Marxist narrative of neoliberalism as a dominant ideology of global capitalism. You see such attempts as remaining within the binary oppositions of public and private, collective and individual, and state and market, that Foucauldian research problematises. However, do you think that a theoretical-methodological rapprochement (such as that attempted by Jamie Peck 2013) between Marxist and Foucauldian accounts of neoliberalism is possible - recognising it as a series of changing techniques of government, for example, while also accounting for the influence of private interests and offering a critique of multiple forms of power - or do you (like Stephen Collier 2012) see them as mutually exclusive?

TERRY FLEW: There is a certain irony in saying that one has to view Michel Foucault as a man of his times, given his own pronouncements about the death of the author! But it is important to understand how his work evolved in a kind of critical dialogue with the predominantly Marxist milieu of philosophy and social theory in post-war France. In particular, he railed against the "official Marxism" represented by the Communist Party of France (PCF), with which he had a brief and unhappy relationship. Throughout his work, you can find a critique of three core tenets of Marxian orthodoxy: that the left can transform power in all of its dimensions by virtue of capturing control over the state and its institutional apparatuses; that the mass of people live under a kind of false consciousness derived from capitalist ideology, which prevents them from understanding their 'true' interests; and that the fundamental antagonism of capitalist societies is between bosses and workers. With the 'left' critique of the PCF associated with the May 1968 uprisings, Foucault found a natural affinity with the new social movements who were also critical of such orthodoxies.

By the mid 1970s, however, that moment had exhausted itself, and Foucault's 1978-79 lectures at the College de France are situated in that changed context. The lectures continue his thematic interest in governmentality, or the 'minor' strategies and tactics of power associated with governmental institutions that occur below the surface of the state and the political leadership: the 'King' whose head needed to be 'cut off' in order to better understand what he termed the microphysics of power. At several points he rails against the 'state phobia' and 'paranoiac thinking' of the ultra-left, arguing that liberal modes of government actually seek to reduce the power of the state, or at least to disperse its operations through the social 
body. It is this which he argues that the neo-liberal theorists have understood better than the Marxists, that 'reason of state' is the more effective the more it can operate through civil society and through individuals themselves, rather than be imposed from above. Contemporary variants of such thinking can be found in behavioural economics and so-called 'nudge theory'.

At the same time, he was also sceptical about the 'Common Program' that had been adopted by the Socialist Party (PS) and the PCF. This program, which formed the basis for an uneasy alliance among the two leading parties of the left, set out a programmatic statement of what a government of the left needed to do if they came to power, and was seen by the PCF in particular as heralding a transition from capitalism to socialism, involving the nationalisation of the largest companies, comprehensive economic planning etc. His commentary on this is more indirect, but links to his propositions that power is not simply something held in the state apparatuses, or located in the economic base. He observes that what is missing here is an 'art of government', or what he describes as 'a reasonable and calculable measure of the extent, modes, and objectives of governmental action' (Foucault 2008, pp. 91-92). Again he thinks that the left can learn from the neoliberals, but in this instance it is about how to align philosophical ideals with practical programs of government. He is critiquing the left for its focus on doctrinal conformity (e.g. how many companies should be nationalised - 50, 250 ???), and arguing that the neoliberals have a better understanding of change as a process, embedded in the practical tasks of government. In other words, the left needs to be less 'textualist' and more pragmatic.

The question now, of course, is whether he implicitly endorsed the sort of government through the market, audit culture, enterprise culture etc. that we associated with neoliberal modes of government in the late 20th and early 21st centuries. This is debated at length in the recent collection edited by Daniel Zamora and Michael Behrent, titled Foucault and Neoliberalism (Zamora 2015). Given the time at which Foucault was presenting these lectures - 1978 in France - it is amazing that he was not looking at what was going on across the channel with the rise of Margaret Thatcher to power in the U.K. Thatcher would give concrete form to many of the ideas that largely existed at the level of speculation in late 1970s France. He was probably overly sanguine about government through the market, with his by then largely residual anti-statism coming up against a political position that was at the time of his death closer to Scandinavian social democracy than anything else. Had he lived into the 1990s, he may have become a "Third Way" theorist :-)! But such speculation serves little purpose: the main point would be that he pursued a critique of Marxism from the perspective of someone who understood the theory well, and this makes it difficult to synthesise Foucault's work into neo-Marxist theories of hegemony along the lines that this question proposes.

SIMON DAWES: While others have debated the extent to which Foucault's reading of neoliberalism is compatible with a Marxist approach or even critique more generally, you've 
recently $(2014 ; 2015)$ teased out the Weberian influence on Foucault's lectures on neoliberalism, linking Foucault's account of historical change to Weber's work on the economic sociology of national capitalisms. How can linking Foucault and Weber help us understand neoliberalism, as well as contribute to the kind of reflexive comparative analysis of national media systems that you advocate?

TERRY FLEW: There is a lot of talk about convergence in media studies. We largely use the term to discuss technological convergence, and related developments like industry convergence (the rise of Google, Facebook, etc. and their challenge to traditional media giants), textual convergence (e.g. transmedia storytelling) and content convergence around digital platforms. But implicit in theories of neoliberalism is the idea that we are experiencing greater policy convergence, and that the world is shifting from models of media regulation with a high role of government involvement towards deregulation, privatisation of public broadcasters, and the marketisation of access to media content. It is also proposed that media globalisation is making the study of comparative media systems redundant, as increasingly mobile and diasporic populations use new technologies to access content from around the globe, and are less and less anchored to territorially-defined national media systems.

One of the interesting things about Max Weber's work, and Foucault's use of Weber, is that it reasserts the need for comparative work on institutions and national systems of government. The arguments that 'the history of capitalism can only be an economic-institutional history' (Foucault 2008, p. 162), and that legal relations are not the consequence of economic relations but are in fact foundational to economic relations - a proposition that goes back to Emile Durkheim, and has been a staple of economic sociology since Max Weber and Karl Polanyi bring a new understanding to media policy that avoids simply seeing it as the by-product of a malign political ideology of global neoliberalism. A core concept of institutionalism is the idea of path dependency: the idea that institutional structures have histories that shape their responses to new developments, not least because an institution is a cultural as much as a social, political or economic entity, and that the way people think within institutions is shaped by that history. This implies that alongside the forces for policy convergence, such as international trade agreements or the 'policy transfer' of particular ideas and ideologies, we need to be noting the deep structure of institutional forms, and the informal institutions associated with values, customs, beliefs etc. that have long histories within nation-states, and continue to shape their political economies. The new institutional economists such as Douglass North, as well as critical economic theorists such as Geoffrey Hodgson, have been alert to these issues.

For those arguing that media globalisation is making national media systems redundant, I would say not so fast. A recent collection of essays that I have co-edited, along with Petros Iosifidis (City) and Jeanette Steemers (Westminster) is titled Global Media and National Policies: The Return of the State (Flew et. al., 2016). In that collection, various authors argue the case for the primary dynamics of media continuing to be national, even as the national and the transnational increasingly co-exist. As well as the on-going cultural dynamics of audience preference for local content where it is readily available, there are the policy dynamics of 
incumbent media continuing to have strong proximity to national political decision-makers, and the ways in which they can promote regulations to maintain a national media space.

Indeed, one of the fastest areas of growth in contemporary media has been the international expansion of national broadcasters, with the rise of CCTV, Russia Today, Telesur, Press TV, Al-Jazeera and others, alongside expansion of the international operations of the BBC, Deutsche Velle, France 24 and NHK. This is associated with the struggle for political hegemony in a post-Cold War world, and the idea of cultural soft power through international broadcasting being an important arm of a nation's public diplomacy. At one level, this can be seen as media globalisation, but it is a globalisation very much orchestrated by national governments, for their own national political purposes. Whether we are in a post-globalisation era remains to be seen, but there is much evidence of the continuing centrality of the Westphalian system of states.

\section{References}

Collier, S. (2012) 'Neoliberalism as Big Leviathan, or...? A Response to Wacquant and Hilgers', Social Anthropology, 20(2)

Couldry, N. (2010) Why Voice Matters: Culture and Politics After Neoliberalism, London: SAGE

Flew, T. (2009) 'The citizen's voice: Albert Hirschman's Exit, Voice and Loyalty and its contribution to media citizenship debates', Media, Culture \& Society, 31(6)

Flew, T. (2012) 'Michel Foucault's The Birth of Biopolitics and contemporary neoliberalism debates', Thesis Eleven, 108(1)

Flew, T. (2013) 'FactCheck: does Murdoch own 70\% of newspapers in Australia?', The Conversation, https://theconversation.com/factcheck-does-murdoch-own-70of-newspapers-in-australia-16812

Flew, T. (2014) 'Six theories of neoliberalism', Thesis Eleven, 122(1)

Flew, T. (2015) 'Foucault, Weber, Neoliberalism and the Politics of Governmentality', Theory, Culture \& Society, 32(7-8)

Flew, T. and Waisbord, S. (2015) 'The ongoing significance of national media systems in the

context of media globalization', Media, Culture \& Society, 37(4)

Flew, T., Iosifidis, P. and Steemers, J. (2016) 'Global Media and National Policies: The Return of the State', in Flew, T., Iosifidis, P., and Steemers, J. (eds.) Global Media and National Policies: The Return of the State. Basingstoke: Palgrave Macmillan, pp. 1-15.

Foucault, M., Senellart, M. and Burchell, G. (2008) The Birth of Biopolitics: Lectures at the college de France, 1978-1979. Edited by Arnold I. Davidson, Alessandro Fontana, and Francois Ewald. New York: Palgrave Macmillan.

Peck, J. (2013) 'Explaining (with) Neoliberalism', Territory, Politics, Governance, 1(2)

Piketty, T. (2014) Capital in the Twenty-First Century. Cambridge, MA: Harvard University Press. 
Productivity Commission (2000) Broadcasting: Final Report. Canberra: Ausinfo.

Zamora, D. (2015) 'Foucault, the Left, and the 1980s', in Zamora, D. and Behrent, M. (eds.) Foucault and Neoliberalism. London: Verso, pp. 1-5.

Terry Flew is a Professor of Media and Communication in the Creative Industries faculty at the Queensland University of Technology in Brisbane, Australia. He is the author of Australia's leading new media textbook, New Media: An Introduction (2002). He is also the author of Media Economics (2015), co-authored with Stuart Cunningham and Adam Swift, Global Creative Industries (Polity, 2013), Creative Industries, Culture and Policy (Sage, 2012), Key Concepts in Creative Industries (Sage, 2013), and Understanding Global Media (Palgrave, 2007). He has also edited Global Media and National Policies: The Return of the State (2015), co-edited with Petros Iosifidis and Jeanette Steemers, and Creative Industries and Urban Development: Creative Cities in the 21st Century (Routledge, 2012).

Email: t.flew@qut.edu.au

Simon Dawes is the editor of Networking Knowledge - the Journal of the MeCCSA PGN, editorial projects \& website manager of Theory, Culture \& Society and Body \& Society, and editor of the media \& communication studies section of the Open Library of Humanities. $\mathrm{He}$ teaches at Université Paul Valéry, Montpellier, France. His research revolves around issues of media theory, history and regulation. Currently, he is writing a monograph based on his $\mathrm{PhD}$ thesis, Broadcasting and the Public-Private Dichotomy (forthcoming, Palgrave Macmillan).

Email: simondawes0@gmail.com 